\title{
Economic viability of a monitoring system in mechanized citrus production
}

\section{Avaliação econômica de sistema de monitoramento em operações mecanizadas na citricultura}

\author{
Josivan Alves da SILVA ; David Ferreira Lopes SANTOS ${ }^{2}$; Diego Onofre VIDAL \\ Rouverson Pereira da SILVA ${ }^{4}$; Stela Basso MONTORO 5
}

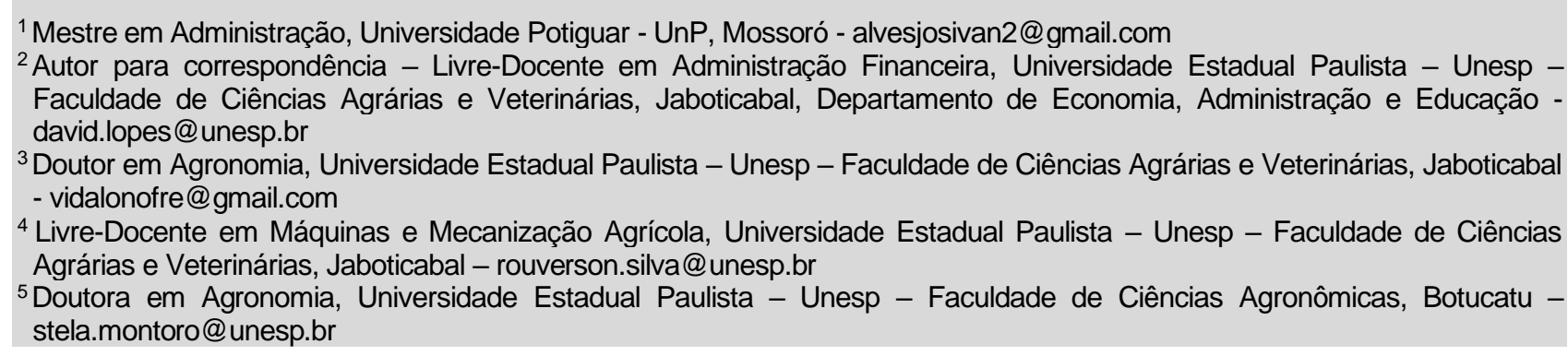

Recebido em: 09-05-2019; Aceito em: 26-03-2020

\begin{abstract}
Digital agriculture is currently the main technological paradigm in agribusiness, in which one of the main challenges is the convergence of new monitoring technologies with the management of the volume of information generated to increase productivity. This research analyzes the economic viability of a monitoring system deployed on eight tractors and two trucks used for spraying operations in a citrus farm. The operations covered an area of 2,236 ha and were performed during the 2016/2017 harvest. The economic results of the investment were examined using the discounted cash flow method associated with the Monte Carlo simulation. The monitoring system provided greater availability and quality of information, which improved the quality of operations management. The results pointed to $23.67 \%$ lower costs per hectare in monitored compared to unmonitored areas. Economic analysis demonstrated the viability of the investment with $99.5 \%$ confidence, whose gain in Net Present Value per machine represents $15 \%$ of the machine acquisition cost. The results of this study are pioneering for mechanized citrus operations and denote the importance of investments in automated digital monitoring systems that allow better monitoring of management activities in orange production.
\end{abstract}

Additional keywords: agribusiness; digital agriculture; monitoring system; Monte Carlo simulation; plant health; spraying.

\section{Resumo}

A agricultura digital é o principal paradigma tecnológico na atualidade para o agronegócio, em que um dos principais desafios é a convergência de novas tecnologias de monitoramento com a gestão do volume de informações geradas para o aumento da produtividade. Esta pesquisa analisa a viabilidade econômica de um sistema de monitoramento, implantados em oito tratores e dois caminhões utilizados em operações de pulverização em uma empresa rural dedicada à citricultura em uma área de 2.236 ha durante a safra 2016/217. Por meio da metodologia do fluxo de caixa descontado associado à simulação de Monte Carlo examinou-se os resultados econômicos do investimento. Verificou-se que a maior disponibilidade e qualidade das informações, coletadas pelo sistema, permitiram melhorias na qualidade do gerenciamento das operações, de modo que os resultados reportaram custos inferiores em $23,67 \%$ /ha nas áreas com operações monitoradas, frente as demais. A análise econômica demonstrou a viabilidade do investimento com $99,5 \%$ de confiança, cujo ganho em Valor Presente Líquido por máquina representa $15 \%$ do valor de aquisição da mesma. Os resultados deste estudo são pioneiros para as operações mecanizadas na citricultura e denotam a importância dos investimentos em sistema automatizados de monitoramento digital que permitam o melhor gerenciamento das atividades de manejo na produção de laranja.

Palavras-chave adicionais: agricultura digital; agronegócio; fitossanidade; pulverização; simulação de Monte Carlo; sistema de monitoramento. 


\section{Introduction}

Citrus production is one of the fruit growing sectors that puts Brazil in the spotlight (Carvalho et al., 2019). It is a highly organized and competitive sector, being one of the most prominent activities in Brazilian agribusiness (Paulillo \& Neves, 2015). Brazil is responsible for $60 \%$ of the world production of orange juice and is also the largest exporter of this product in the world, which is the fifth most exported in Brazilian agribusiness (FAO, 2017; MAPA, 2016). São Paulo State is the largest orange producer in Brazil, concentrating around 472 thousand ha for cultivation at the end of 2015 (Paulillo \& Neves, 2015).

Despite the economic importance of orange production for Brazil, the economic and financial performance of the activity is characterized by limited margins and profitability for rural producers (Cassia, 2016; Simões et al., 2015). In view of this reality, many national and international studies focus not only on agronomic aspects related to productivity, but also on economic factors with a view to increasing the competitiveness and longevity of citrus farms (Gallardo \& Brady, 2015; Julian \& Seavert, 2011; Simões et al., 2015).

Understanding farms as competitive companies requires a decision-making process that is attentive to the needs of investments in new mechanization technologies, management systems, genetic breeding, infrastructure, and strategic market positioning decisions (Banchi \& Lopes, 2015; Müller et al., 2011).

In this sense, the analysis and evaluation of investments in information systems aimed at monitoring citrus farming operations is still a technological paradigm both in the operational and managerial fields, in spite of its growing use in other agricultural activities and crops (Voltarelli et al., 2015a).

Information management is a technological frontier in production management due to the potential for improving operational and economic performance. The biggest challenge in generating and managing agricultural information (through the field known as Digital Agriculture) is the effective implementation of more technically and economically viable systems for the producer (Massruhá \& Leite, 2016; Janssen et al., 2017; López-Riquelme et al., 2017).

Investment analysis is a central issue in financial theory, whose applications in agriculture do not always preserve the foundations required for quality decision making (Santos et al., 2016). Theoretical conflicts stem from the use of the 'traditional' cash flow structure that does not preserve cost elements, being associated only with investment (Matsunaga et al., 1976) and the inconsistent treatment of risk that determines the discount rate (Farinelli et al., 2018).

According to Assaf Neto (2005), cash flow is the tool that portrays all the inflows and outflows of the company's cash, the result being the balance available in the company's cash at a given time, be it day, month, or year. According to Gitman (2004) and Assaf Neto
(2005), the value of a business depends on its future free cash flows, discounted at present value by an appropriate minimum attractiveness rate that incorporates the risks inherent in future cash flows.

However, although efficient, the discounted cash flow model is deterministic, comprising a series of uncertainties regarding the estimates of future cash flows of the business (Buratto, 2005). Thus, studies suggest the use of stochastic tools such as the Monte Carlo simulation, which makes it possible to incorporate into the model the risk that each of the estimated variables may assume a different value than expected (Oliveira \& Mederios Neto, 2012; Simões et al., 2015). The probabilistic components of the stochastic model reduce uncertainties in decision making and allow other analyses that are impossible to be performed using a conventional deterministic model (Buratto, 2005; Oliveira \& Medeiros Neto, 2012).

The Monte Carlo simulation is a probabilistic model that can be used in several areas of knowledge, having great practical applicability. Several authors highlight the importance of using this model to solve practical problems in different areas such as engineering, medical, economic, and physical sciences. It can be used, for instance, to solve everyday problems with suitable mathematical models (Sabbag \& Costa, 2015; Ribeiro \& Franco, 2017; Oliveira et al., 2019; Amorim et al., 2019).

Investment analysis based on the construction of the stochastic simulation model is an unexplored theme in studies involving the economic evaluation of new technologies applied to agriculture, increasing the importance of assessing the financial risks of technological innovations to the citrus industry (Simões et al., 2015; Ribeiro \& Franco, 2017). What is noticeable is that either there is little adherence to the theoretical financial assumptions, or they occur under strict evaluation precepts (Faleiros et al., 2018).

In this context, this study analyzes the economic viability of investing in a computerized system for monitoring agricultural operations in a citrus company. The system is based on real-time monitoring of agricultural operations performed with the use of tractors. This technology allows: i) controlling the activities performed on all work fronts; ii) anticipating changes in the planning and execution of activities as new information is known on different work fronts; iii) correcting problems associated with equipment malfunction and increasing control over its use, maintenance, and fuel consumption.

Although qualitative benefits are multiple and can improve efficiency in mechanized citrus operations, this technology includes expenses related to equipment acquisition and incremental expenses for system maintenance. Moreover, it requires professionals to monitor the activities, training for the correct use of equipment, and the management of change along with employees. Thus, there is a need to analyze this investment from its implementation, in addition to identifying and valuing uncertainties associated with cash flow. 
To better present the results of the study, this article is organized as follows. The next section describes the materials and methods used to collect data, in addition to the quantitative and financial procedures used to build the research results. Section 3 presents the results obtained, which are discussed with the literature. Conclusions are presented in the fourth section and references are listed in the end.

Citrus production is one of the fruit growing sectors that puts Brazil in the spotlight (Carvalho et al., 2019). It is a highly organized and competitive sector, being one of the most prominent activities in Brazilian agribusiness (Paulillo \& Neves, 2015). Brazil is responsible for $60 \%$ of the world production of orange juice and is also the largest exporter of this product in the world, which is the fifth most exported in Brazilian agribusiness (FAO, 2017; MAPA, 2016). São Paulo State is the largest orange producer in Brazil, concentrating around 472 thousand ha for cultivation at the end of 2015 (Paulillo \& Neves, 2015).

Despite the economic importance of orange production for Brazil, the economic and financial performance of the activity is characterized by limited margins and profitability for rural producers (Cassia, 2016; Simões et al., 2015). In view of this reality, many national and international studies focus not only on agronomic aspects related to productivity, but also on economic factors with a view to increasing the competitiveness and longevity of citrus farms (Gallardo \& Brady, 2015; Julian \& Seavert, 2011; Simões et al., 2015).

Understanding farms as competitive companies requires a decision-making process that is attentive to the needs of investments in new mechanization technologies, management systems, genetic breeding, infrastructure, and strategic market positioning decisions (Banchi \& Lopes, 2015; Müller et al., 2011).

In this sense, the analysis and evaluation of investments in information systems aimed at monitoring citrus farming operations is still a technological paradigm both in the operational and managerial fields, in spite of its growing use in other agricultural activities and crops (Voltarelli et al., 2015a).

Information management is a technological frontier in production management due to the potential for improving operational and economic performance. The biggest challenge in generating and managing agricultural information (through the field known as Digital Agriculture) is the effective implementation of more technically and economically viable systems for the producer (Massruhá \& Leite, 2016; Janssen et al., 2017; López-Riquelme et al., 2017).

Investment analysis is a central issue in financial theory, whose applications in agriculture do not always preserve the foundations required for quality decision making (Santos et al., 2016). Theoretical conflicts stem from the use of the 'traditional' cash flow structure that does not preserve cost elements, being associated only with investment (Matsunaga et al., 1976) and the inconsistent treatment of risk that determines the discount rate (Farinelli et al., 2018).

According to Assaf Neto (2005), cash flow is the tool that portrays all the inflows and outflows of the company's cash, the result being the balance available in the company's cash at a given time, be it day, month, or year. According to Gitman (2004) and Assaf Neto (2005), the value of a business depends on its future free cash flows, discounted at present value by an appropriate minimum attractiveness rate that incorporates the risks inherent in future cash flows.

However, although efficient, the discounted cash flow model is deterministic, comprising a series of uncertainties regarding the estimates of future cash flows of the business (Buratto, 2005). Thus, studies suggest the use of stochastic tools such as the Monte Carlo simulation, which makes it possible to incorporate into the model the risk that each of the estimated variables may assume a different value than expected (Oliveira \& Mederios Neto, 2012; Simões et al., 2015). The probabilistic components of the stochastic model reduce uncertainties in decision making and allow other analyses that are impossible to be performed using a conventional deterministic model (Buratto, 2005; Oliveira \& Medeiros Neto, 2012).

The Monte Carlo simulation is a probabilistic model that can be used in several areas of knowledge, having great practical applicability. Several authors highlight the importance of using this model to solve practical problems in different areas such as engineering, medical, economic, and physical sciences. It can be used, for instance, to solve everyday problems with suitable mathematical models (Sabbag \& Costa, 2015; Ribeiro \& Franco, 2017; Oliveira et al., 2019; Amorim et al., 2019).

Investment analysis based on the construction of the stochastic simulation model is an unexplored theme in studies involving the economic evaluation of new technologies applied to agriculture, increasing the importance of assessing the financial risks of technological innovations to the citrus industry (Simões et al., 2015; Ribeiro \& Franco, 2017). What is noticeable is that either there is little adherence to the theoretical financial assumptions, or they occur under strict evaluation precepts (Faleiros et al., 2018).

In this context, this study analyzes the economic viability of investing in a computerized system for monitoring agricultural operations in a citrus company. The system is based on real-time monitoring of agricultural operations performed with the use of tractors. This technology allows: i) controlling the activities performed on all work fronts; ii) anticipating changes in the planning and execution of activities as new information is known on different work fronts; iii) correcting problems associated with equipment malfunction and increasing control over its use, maintenance, and fuel consumption.

Although qualitative benefits are multiple and can improve efficiency in mechanized citrus operations, this technology includes expenses related to equipment acquisition and incremental expenses for system maintenance. Moreover, it requires professionals to 
monitor the activities, training for the correct use of equipment, and the management of change along with employees. Thus, there is a need to analyze this investment from its implementation, in addition to identifying and valuing uncertainties associated with cash flow.

To better present the results of the study, this article is organized as follows. The next section describes the materials and methods used to collect data, in addition to the quantitative and financial procedures used to build the research results. Section 3 presents the results obtained, which are discussed with the literature. Conclusions are presented in the fourth section and references are listed in the end.

\section{Material and methods}

This research was carried out in a citrus farm specialized in orange (Citrus sinensis) production, located in the interior of São Paulo State. The object of study was the fleet monitoring system, based on the Global Positioning System (GPS) technology, with implementation of eight tractors and two trucks for the spraying of orchards.

Economically, this investment for better fleet management is expected to allow the company to improve the efficiency of resources (tractors, implements, trucks, people, among others), therefore contributing to reduce company costs.

To measure the potential of the system, the study evaluated five work fronts throughout the 2016/2017 harvest: two work fronts with monitored equipment and three fronts with unmonitored equipment. All fronts consisted of 1 truck and 4 tractors. The work fronts covered an area of 2,236 ha, in which three spraying activities were evaluated: Control of Citrus Black Spot; Control of Psyllids; and Control of Colletotrichum or Postbloom Fruit Drop.

All data referring to costs and worked hours were made available by the company. One of the authors of the study participated directly in the entire implementation process. To eliminate bias, in addition to documentary analysis, the other authors of this study performed 25 on-site visits to the company. In addition to direct observation, the visits included 21 interviews with the company professionals directly involved with the investment and with company directors.

The projection of future cash flow considered the 5 years following the survey due to the expected operational life of the GPS. This information was obtained in consultation with the supplier of the monitoring technology and company technicians. Thus, it is expected that in up to 5 years the tractors will receive new monitoring technologies and other implements used in citrus farming, making current equipment obsolete.

The analysis techniques for economic evaluation of the project were the two main ones of Discounted Cash Flow (DCF): Net Present Value (NPV) and Internal Rate of Return (IRR), these being widely used in the evaluation of agricultural projects (Costa et al., 2015).

However, the conceptual cash flow structure used only the variables that have an impact on cash, as explained by Santos et al. (2016), without adding nonpayable costs such as opportunity costs and financial costs associated with indebtedness (Matsunaga et al., 1976). Therefore, monitored activities were compared to unmonitored ones for their performance based on the cash flow structure for this investment. The difference between them shows the one with the highest economic performance considering the DCF method, according to Equation 1 (Ehrhardt \& Brigham, 2010).

$\mathrm{DCF}_{\mathrm{i}}=\sum_{\mathrm{j}=1}^{\mathrm{n}} \frac{\mathrm{FCF}_{\mathrm{j}}}{(1+\mathrm{k})^{n}}$

Wherein:

DCF - Discounted Cash Flow; FCF - Free Cash Flow; $\mathrm{n}$ : time; $\mathrm{k}$ : discount rate.

The discount rate used in this study was estimated from the Capital Assets Pricing Model (CAPM) (Ehrhardt \& Brigham, 2010), according to Equation 2.

$k=R f+\beta \times(R m-R f)$

Wherein:

$\mathrm{Rf}$ is the risk-free rate; $\beta$ is the beta coefficient, a measure of the systematic (nondiversifiable) risk of the asset; and $\mathrm{Rm}$ is the market return.

The assumptions used were: the Brazilian riskfree rate (Selic) of 5.5\% (real rate) in 2016; the average systematic risk (beta) of 0.914 , resulting from the covariance of returns on assets of the agricultural companies BrasilAgro, PomiFrutas, and SLC Agrícola with the market return of B3 (considering the 2016/2013 period); and the historical Brazilian market premium of $6 \%$ p.y.. Thus, the discount rate was determined at $11 \%$ p.y.. This procedure was similar in other studies (Faleiros et al., 2018; Farinelli et al., 2018). The calculation is shown in Equation 3:

$k=0,055+0,917 \times 0,06$

Three cash flows were prepared: 1) Cash flow from unmonitored activities; 2) Cash flow from monitored activities; and 3) Incremental cash flow, given by the difference between the flow of unmonitored and monitored activities. The values that make up the cash flow are average values both from monitored and unmonitored activities. The identified variations were worked on the Monte Carlo simulation model, being performed in the @RISK software to increase the robustness of the results. According to Oliveira \& Pamplona (2012), when not using historical data, an alternative is to use the Monte Carlo simulation to estimate cash flow volatility. The authors add that in the Monte Carlo method, the main sources of uncertainty for 
the project, such as revenues, discount rates, costs and expenses, taxes and depreciation, among others, can serve as input variables for the simulation. This was the case of the present study, in which all cash inflow and outflow variables were used as input variables for the model.

For this study, the number of simulations to be performed was defined to be 10,000 . According to Oliveira and Medeiros Neto (2012), this quantity is large enough to allow the results (mean and standard deviation of the output variables) to stabilize, making it possible to obtain graphics with a higher density of points.

Silva et al. (2011) highlight that when incorporated into finance models, this method provides approximations for the probability distributions of the parameters. These models have been studied with several simulations, each of them generating random values for the set of input variables and model parameters that are subject to uncertainty. The need to use the Monte Carlo simulation was due to the high variability of costs per hectare, as verified throughout the 2016/2017 crop, according to Table 2.

We chose to use triangular distributions to model input variables due to the variability of costs and the knowledge of minimum, average, and maximum values for each activity after extensive survey on cost records of the activities performed by the company
(Mun, 2002). The triangular distribution is easy to understand, only requiring parameters of intuitive meaning, that is, a minimum, probable, and maximum value expected for the variable in question. This distribution is very useful when the source of information for the definition of parameters is decentralized (Buratto, 2005), as is the case of this study, in which data were provided by the analyzed company.

We opted to express the values in dollars for the purpose of comparing with other markets, using the exchange rate in force at the time of the conclusion of the analysis, which was $R \$ 3.2998$ per USD 1.00 .

\section{Results and discussions}

The main benefit of the monitoring system is the possibility of better managing the resources applied in the activity (Xia et al., 2015; Choi et al., 2015; Voltarelli et al., 2015b). The project cash flow can be seen in Table 1, as well as the values referring to the impact of the monitoring system on the costs of each spraying activity compared to the traditional work system hitherto used by the company.

As the average values are the same for the entire cycle, Table 1 shows the Present Value (PV) of each of the activities; in this sense, annual values can be obtained by the Equivalent Annual Cash Flow.

Table 1 - Project cash flow (USD).

\begin{tabular}{lcrrr}
\hline \multirow{2}{*}{ Activity } & \multicolumn{4}{c}{ Present Value } \\
& Unmonitored & Monitored & Incremental & Variation \\
\hline Control of Black Spot & $\mathbf{1 , 2 8 2 , 8 2 3}$ & $\mathbf{9 8 9 , 3 5 6}$ & $\mathbf{2 9 3 , 4 6 6}$ & $-22.88 \%$ \\
Equipment & 785,756 & 596,469 & 189,288 & $-24.09 \%$ \\
Labor & 497,066 & 392,888 & 104,178 & $-20.96 \%$ \\
Control of psyllids & $\mathbf{2 , 0 1 6 , 0 9 4}$ & $\mathbf{1 , 6 3 8 , 8 7 3}$ & $\mathbf{3 7 7 , 2 2 1}$ & $-18.71 \%$ \\
Equipment & $\mathbf{1 , 2 2 8 , 4 1 2}$ & 926,006 & 302,406 & $-24.62 \%$ \\
Labor & 787,682 & 712,867 & 74,814 & $-9.50 \%$ \\
Control of Colletotrichum & $\mathbf{2 9 8 , 6 6 8}$ & $\mathbf{2 8 0 , 8 3 2}$ & $\mathbf{1 7 , 8 3 6}$ & $-5.97 \%$ \\
Equipment & 180,457 & 152,399 & 28,059 & $-15.55 \%$ \\
Labor & 118,211 & 128,433 & 10,222 & $8.65 \%$ \\
Total Cost & $\mathbf{3 , 5 9 7 , 5 8 5}$ & $\mathbf{2 , 9 0 9 , 0 6 2}$ & $\mathbf{6 8 8 , 5 2 3}$ & $-19.14 \%$ \\
Incremental Expenses & - & 114,244 & 114,244 & - \\
Total Costs and Expenses & $\mathbf{3 , 5 9 7 , 5 8 5}$ & $\mathbf{3 , 0 2 3 , 3 0 6}$ & $\mathbf{5 7 4 , 2 7 9}$ & $-15.96 \%$ \\
Income Tax & $\mathbf{1 , 2 2 3 , 1 7 9}$ & $\mathbf{1 , 0 2 7 , 9 2 4}$ & 195,255 & $-15.96 \%$ \\
Operating Cash Flow & $\mathbf{2 , 3 7 4 , 4 0 6}$ & $\mathbf{1 , 9 9 5 , 3 8 2}$ & $\mathbf{3 7 9 , 0 2 4}$ & $-15.96 \%$ \\
Investment & - & 9,698 & 9,698 & - \\
Free Cash Flow & $\mathbf{2 , 3 7 4 , 4 0 6}$ & $\mathbf{1 , 9 8 5 , 6 8 4}$ & $\mathbf{3 8 8 , 7 2 2}$ & $-16.37 \%$ \\
\hline
\end{tabular}

Source: Research data (elaborated by the authors).

Monitored operations had a lower cost when compared to unmonitored ones in all activities, except for labor in spraying Colletotrichum, which presented an incremental cash flow with positive variation, since the costs inherent in monitored operations were lower than those of unmonitored activities. These results allow us to infer that the monitoring of spraying activities contributes significantly to cost reduction, which ranged between $5.97 \%$ and $24.09 \%$.
The decrease in costs from the monitoring of operations can be explained by the capture of information and its processing in on-board computers, feeding the server database. According to Regattieri et al. (2018), information capture and processing reduces human error and enables reliability of the information recorded by operators on the hour meter, since all notes of operations are validated by the parameters monitored by the on-board computer. In this sense, it is also 
noteworthy the digitization of the information that is also passive of human error when transcribing written texts into the system.

Incremental expenses refer to the charges in hiring a professional who started to manage the system in real time during activities. The importance of this professional was verified during the monitoring of the project, through visits and interviews, since he/she is responsible for planning, organizing, and controlling all equipment distributed throughout the area. Thus, the company started to identify the causes of inadequate planning of work routines (logistics, preparation of inputs for use in machines, correct use of equipment, among others), in addition to improving the planning of equipment distribution throughout the entire area and identifying production stops.

The values in Table 1 are shown in present values. Thus, the line that represents the FCF brings the valuation of monitored, unmonitored, and incremental activities. Note that the incremental FCF is positive, this means that the project has evaluated economic viability, as gains in present value resulting from the monitoring process are superior to investment and operations conducted unmonitored.

The need of the agricultural company to control these operations is also justified by the fact that it is located in São Paulo State, where, since 2000, more than $20 \%$ of the orange groves have been lost due to phytosanitary aspects linked to the crop. The concern with treating these aspects in a preventive way becomes more economically viable, given the impact they cause when treated in a defensive way (Neves \& Kalaki, 2015). In view of the above, the effective reduction of costs with the monitoring of activities encourages the use of technologies that prevent negative impacts on crops (Novaes \& Santos, 2017)

The values intended for preventive spraying are also aligned with the gaps identified by Scaloppi et al. (2012). These authors found that, despite the direct and indirect risks related to phytosanitary aspects, the levels of control of these activities in citrus have been below the desirable ones, requiring an integrated management and the use of available techniques and technologies to measure and control production.

Still regarding the values in Table 1, it is worth mentioning the observation made by Ferreira (2014), who debated the fact that phytosanitary aspects in citrus crop account on average for one third of the production costs, and half of this value is used for spraying activities. According to Banchi \& Lopes (2015), mechanization costs started to represent the second main component of production costs in rural activity, inputs being the main one.

In this way, Regattieri et al. (2018) emphasize the importance of monitoring for the management of the agricultural fleet (basic maintenance, supply point, mechanical workshop, preventive maintenance, licensing and insurance, implements, costs, materials, and aggregates). Barros and Milan (2010) state that remote communication tools have been used to instantly know the current state of production operations, aiming to reduce costs and improve production.

It is also observed that the activity of psyllids was the one with the highest cost of control, corresponding on average to $55 \%$ of the total cost of spraying. The control of citrus black spot accounted for $42 \%$ of the total cost, and the control of Colletotrichum accounted for $3 \%$. The two most expensive activities were the cheapest when comparing monitored and unmonitored teams, which corroborates the importance of the monitoring system.

Casais et al. (2014) state that huanglongbing (HLB), or citrus greening, has been considered the worst and most destructive disease affecting commercial citrus groves worldwide. In view of this reality, psyllid control alone represents $55 \%$ of the total cost of spraying, with preventive expenses being more pertinent than the risk of the biological and financial damages that may be caused.

As mentioned above, psyllid control was the second most expensive activity in the analysis. According to Bernardo and Bettiol (2010), psyllid is the main pest affecting the citrus crop in São Paulo State, which is one of the probable reasons why controlling this activity is almost as expensive as controlling HLB.

Scaloppi et al. (2012) add that the main commercial varieties of sweet orange are susceptible to the pathogen, which commercially depreciates the fruit for the fresh market. Moreover, this pathogen causes the fruit to fall before harvest, which is financially prejudicial, justifying the investment in defensive pest control.

Finally, the control of postbloom fruit drop of citrus is justified by Spada (2011), who identified that this pest affects flowers of practically all commercial varieties, causing premature fruit fall. In addition, Tank Junior (2013) adds that PFD can cause up to $80 \%$ fruit drop. Another factor that may justify a lower cost of controlling this pest is the fact that spraying occurs at specific times of the harvest, unlike HLB.

Nam et al. (2017) realized that traditional management of manual irrigation facilities faces critical limitations such as delays/losses resulting from data handling errors and facility misidentification. The authors demonstrated that an information system for managing irrigation facilities is more efficient when it includes a wireless sensor network (WSN) that uses information and communication technologies (ICTS). The results of the operation demonstrated the applicability of ICTs and WSNs in managing agricultural water resources and provided good portability, object recognition, and information collection in the field.

Due to the large number of single monitored operations throughout the 2016/2017 crop cycle, it was possible to identify that the average values presented in Table 1 showed variability due to the learning process with technology and climatic and even organizational factors. Thus, Table 2 presents the minimum, average, and maximum costs, in addition to the standard deviation for each of the spraying activities performed by the farm for the analyzed period. 
Table 2 - Costs by activity in the monitored area (USD).

\begin{tabular}{lcccc}
\hline Activity & $\begin{array}{c}\text { Average cost } \\
\text { per hectare }\end{array}$ & $\begin{array}{c}\text { Minimum cost } \\
\text { per hectare }\end{array}$ & $\begin{array}{c}\text { Maximum cost } \\
\text { per hectare }\end{array}$ & Volatility of costs \\
\hline Control of Black Spot & $\mathbf{7 . 0 6}$ & $\mathbf{5 . 2 0}$ & $\mathbf{8 . 9 2}$ & 1.86 \\
Equipment & 4.23 & 3.27 & $\mathbf{5 . 1 9}$ & 0.96 \\
Labor & 2.83 & 1.94 & $\mathbf{3 . 7 3}$ & 0.90 \\
Control of Psilídeo & $\mathbf{4 . 6 8}$ & $\mathbf{2 . 8 8}$ & $\mathbf{6 . 4 8}$ & 1.80 \\
Equipment & 2.61 & 1.42 & $\mathbf{3 . 8 0}$ & 1.19 \\
Labor & 2.07 & 1.46 & $\mathbf{2 . 6 8}$ & 0.61 \\
Control of Coletotrichum & 4.98 & $\mathbf{2 . 5 2}$ & $\mathbf{7 . 4 5}$ & 2.46 \\
Equipment & 2.74 & 1.17 & $\mathbf{4 . 3 1}$ & 1.57 \\
Labor & 2.24 & 1.35 & $\mathbf{3 . 1 4}$ & 0.89 \\
Total Cost & $\mathbf{1 6 . 7 3}$ & $\mathbf{1 0 . 6 1}$ & $\mathbf{2 2 . 8 5}$ & 6.12 \\
\hline
\end{tabular}

Source: Research data (elaborated by the authors).

After processing the values in Table 2, the results obtained with the adoption of the monitoring equipment, through the on-board computer, signaled for an economically viable project. In the studied scenario, monitored sectors had a lower cost of operation in practically all activities when compared to unmonitored sectors.

The savings generated in these operations were sufficient to guarantee the company the value of the investment plus a return that corresponds to the financial difference of monitored and unmonitored activities.

Based on the Monte Carlo simulation, the probability of obtaining a negative NPV (the present value of the monitored system being less than that of the unmonitored system) is less than $0.5 \%$, as shown in Table 3.

Table 3 - Probability distribution, obtained in the Monte Carlo simulation.

\begin{tabular}{ccr}
\hline Probability & Risk & NPV (USD) \\
\hline $1 \%$ & $99 \%$ & $65,190.74$ \\
$5 \%$ & $95 \%$ & $272,166.93$ \\
$10 \%$ & $90 \%$ & $383,499.32$ \\
$15 \%$ & $85 \%$ & $461,950.31$ \\
$20 \%$ & $80 \%$ & $523,780.49$ \\
$25 \%$ & $75 \%$ & $584,321.01$ \\
$30 \%$ & $70 \%$ & $634,682.04$ \\
$35 \%$ & $65 \%$ & $684,279.14$ \\
$40 \%$ & $60 \%$ & $731,238.84$ \\
$45 \%$ & $55 \%$ & $776,082.58$ \\
$50 \%$ & $50 \%$ & $823,893.37$ \\
$55 \%$ & $45 \%$ & $870,957.92$ \\
$60 \%$ & $40 \%$ & $919,340.72$ \\
$65 \%$ & $35 \%$ & $968,892.51$ \\
$70 \%$ & $30 \%$ & $1,017,931.78$ \\
$75 \%$ & $25 \%$ & $1,074,199.29$ \\
$80 \%$ & $20 \%$ & $1,139,972.00$ \\
$85 \%$ & $15 \%$ & $1,214,177.95$ \\
$90 \%$ & $10 \%$ & $1,314,383.21$ \\
$95 \%$ & $5 \%$ & $1,446,679.87$ \\
$99 \%$ & $1 \%$ & $1,699,116.14$ \\
\hline
\end{tabular}

Source: Research data (elaborated by the authors).

The results presented in Table 3 show to a certain degree a trend in the sense that implementing a monitoring system in the spraying of citrus crop is economically viable, since the possibility of obtaining a negative NPV is almost nil.

Table 4 presents the results of the NPV of the project and the main dispersion measures, which favor its economic viability. Except for the minimum value, all other measures are adherent, with emphasis on mode, maximum, and average, which reveal favorable values to the final result of the project. 
Table 4 - Dispersion measures of the project NPV.

\begin{tabular}{lc}
\hline Measure & NPV (USD) \\
\hline Minimum & $-317,041.36$ \\
Maximum & $2,280,102.01$ \\
Mean & $836,631.90$ \\
$90 \%$ Confidence interval & $\pm 5,892.58$ \\
Mode & $744,648.98$ \\
Median & $823,893.37$ \\
Standard deviation & $358,210.35$ \\
Assimetry & 0.1842 \\
Kurtosis & 2.8534 \\
\hline
\end{tabular}

Source: Research data (elaborated by the authors).

In this way, the Monte Carlo technique presents itself as one of the most robust tools in the analysis of investment in environments with uncertainty in the premises that generate the DCF. This evidence corroborates other studies of economic viability in citrus (Paes \& Esperancini, 2006; Simões et al., 2015).

The investment in a monitoring system for mechanized agricultural operations presents itself as an activity much more valuated than those observed by Simões et al. (2015), who evaluated the economic viability of an orange producer under risk conditions in the midwest region of São Paulo State. The risk of a negative NPV in the study by Simões et al. (2015) was $42.8 \%$, while that of the present study, as previously stated, was almost nil $(0.05 \%)$. One of the methodological differences in the study of Simões et al. (2015) is that the authors adopted a stratified rather than a triangular distribution, and 100,000 interactions compared to 10,000 in this research.

Another indicator that favors the monitoring of agricultural activities is the IRR, which was $1058 \%$, while that of Simões et al. (2015) was $7.7 \%$. The expressive value of the IRR presented by the project can be understood when analyzing the costs of spraying activities along with the realized value of the investment so that the monitoring could be carried out, since the amount of capital applied is markedly tenuous when analyzing the value of the total costs of spraying operations.

Toledo et al. (2013) highlighted a relevant aspect to be considered when investing in a monitoring system. The authors stated that various types of information are important in the management of agricultural operations, including the conditions and performance of machines, data on field activities (working time and worked area), data on operational performance (travel speed, fuel consumption, etc.), and data on substances used and material flow (including applied chemicals and fertilizers). The sum of these gains, together with the economic increases from cost reduction, reinforce the financial viability of the project.

Digital agriculture is recognized as a technological innovation tool because it improves economic and management aspects when applied preventively during agricultural production, minimizing losses of agricultural inputs and environmental risks, in addition to maximizing the use of fixed assets (machinery, equipment, and implements) in relation to conventional agriculture (Felisberto et al., 2016; Bernardi et al., 2017; Machado et al., 2018).

\section{Conclusions}

The results of this study demonstrate the importance of improving control systems for agricultural operations through information technology. System acquisition costs have become more accessible, being expanded to applications. Knowing that agricultural activities require lean processes with the maximum efficiency possible, control of mechanized spraying operations in citrus production demonstrates a high potential for cost reduction, with added economic value.

It is noteworthy that these results were obtained because the studied farm has a high level of control of its operating costs. This reality is not common for Brazilian farms, which demonstrates the importance of investments in information and control systems so that decisions can be made based on reliable and real data from each company.

The use of the Monte Carlo simulation in the investment analysis in this activity proved to be correct, especially for combining an activity-based cost structure with the control of resources stratified by labor and equipment. Thus, it is important that the cost structures established by the control bodies in Brazil (National Supply Company) and statistical yearbooks report better detailed information to allow a better cost analysis.

It is important to highlight that the present research is relevant both for academic studies and for business decisions, since several studies aim not only to find cost reduction mechanisms, but also to build an organizational scenario based on more comprehensive and integrated information systems, with a view to reducing asymmetries between employees and managers. 


\section{References}

Assaf Neto A (2005). Finanças Corporativas e Valor. Atlas. 656p.

Amorim FR, Patino MTO Abreu PHC, Santos DFL (2019) Economic and risk evaluation of fertilizer application systems in the sugar cane crop: fixed rate by average and Variable Rate Technology. Custos e @gronegócio online.15(2):146-166.

Banchi AD, Lopes JR (2015) Gerenciamento de Frota: Aspectos sobre gerenciamento de mecanização. In: Belardo GC, Cassia MT, Silva RP (eds) Processos Agrícolas e Mecanização da Cana-de-açúcar. SBEA. p. 547-588.

Barros FF, Milan M (2010) Qualidade operacional do plantio de cana-de-açúcar. Bragantia 69(1):221-229. doi: 10.1590/S0006-87052010000100028.

Bernardi CAC, Bettiol GM, Grego CR, Andrade RG, Rabello LM, Inamasu RY (2017) Ferramentas de agricultura de precisão como auxílio ao manejo da fertilidade do solo. Cadernos de Ciência \& Tecnologia, 32(1/2):211-227. doi: 10.35977/01041096.cct2015.v32.23314.

Bernardo ER, Bettiol W (2010) Controle da pinta preta dos frutos cítricos em cultivo orgânico com agentes de biocontrole e produtos alternativos. Tropical Plant Pathology, 35:37-42. doi: 10.1590/S198256762010000100006

Buratto MV (2005) Construção e avaliação de um modelo de simulação de Monte Carlo para analisar a capacidade de pagamento das empresas em financiamentos de longo prazo. UFRGS (Dissertação de mestrado em Administração).

Carvalho LMD, Carvalho HWLD, Barros ID, Martins CR, Soares Filho, WDS, Girardi EA, Passos OS (2019) New scion-rootstock combinations for diversification of sweet orange orchards in tropical hardsetting soils. Scientia Horticulturae, 243:169-176. doi: 10.1016/j.scienta.2018.07.032

Casais VO, Patrocínio ED, Oliveira SA, Schnadelbach AS, Barbosa CD, Barbosa LV (2014) Diversidade genética de Xylella fastidiosa em regiões produtoras de citros na Bahia. Pesquisa Agropecuária Brasileira, 49(1):26-33. doi: 10.1590/S0100204X2014000100004

Cassia, MT (2016) Cartas de controle para gerenciamento de operações agrícolas mecanizadas. UNESP (Tese de doutorado em Agronomia).

Choi KH, Han SK, Han SH, Park KH, Kim KS, Kim S (2015) Morphology-based guidance line extraction for an autonomous weeding robot in paddy fields. Computers and Electronics in Agriculture, 113:266-274. doi: 10.1016/j.compag.2015.02.014
Costa LD, Azevedo FP, Samanez CP (2015) Estratégias de investimento na indústria brasileira de latas de alumínio: uma análise no contexto dos jogos de opções reais. Revista Brasileira de Gestão de Negócios, 17(57):1246-1263. doi: 10.7819/rbgn.v17i57.2253

Ehrhardt MC, Brigham EF (2010) Administração financeira: teoria e prática. 13a ed. Cengage Learning. 905p.

Faleiros GD, Santos DFL, Corá JE (2018) Analysis of profitability of conservation tillage for a soybean monoculture associated with corn as an off-season crop. Cogent Food \& Agriculture, 4(1): 1-20. doi: 10.1080/23311932.2018.1429699

FAO (2017) Food and Agriculture Organization Corporate Statistical Database. Disponível em: $<$ http://www.fao.org/faostat/en/\#data/QC> (Acesso em 22 dez 2017).

Farinelli JBM, Santos DFL, Fernandes C, Fernandes $\mathrm{MMH}$, Silva MF (2018) Crop diversification strategy to improve economic value in Brazilian sugarcane production. Agronomy Journal, 110(4):1402-1411. doi: 10.2134/agronj2017.10.0578

Felisberto PAC, Godoy LJG, Felisberto G (2016) Índices de cor da folha para monitoramento nutricional de nitrogênio em plantas de pimentão. Científica, 44(2):207-216. doi: 10.15361/19845529.2016v44n2p207-216.

Ferreira MD (2014) Aplicação de Produtos Fitossanitários e Calibração de Pulverizadores Para a Cultura dos Citros. In: Andrade DJ, Ferreira MC, Martinelli NM (eds) Aspectos da Fitossanidade em Citros, 1a ed, Cultura Acadêmica. p.245-265.

Gallardo RK, Brady MP (2015) Adoption of labor-enhancing technologies by specialty crop producers: The case of the Washington apple industry. Agricultural Finance Review, 75(4):514-532. doi: 10.1108/AFR-052015-0022

Gitman LJ (2004) Princípios de Administração Financeira. Pearson, $576 p$.

Janssen SJ, Porter $\mathrm{CH}$, Moore AD, Athanasiadis IN, Foster I, Jones JW, Antle JM (2017) Towards a new generation of agricultural system data, models and knowledge products: Information and communication technology. Agricultural systems, 155:200-212. doi: 10.1016/j.agsy.2016.09.017

Julian JW, Seavert CF (2011) AgProfit ${ }^{\mathrm{TM}}$ : a net present value and cash flow based decision aid for agriculture producers. Agricultural Finance Review, 71(3):366-378. doi: 10.1108/00021461111177620 
López-Riquelme JA, Pavón-Pulido N, Navarro-Hellín H, Soto-Valles F, Torres-Sánchez R (2017) A software architecture based on FIWARE cloud for Precision Agriculture. Agricultural Water Management, 183:123135. doi: 10.1016/j.agwat.2016.10.020

Machado J, Shinohara NK, Padilha MR, Silva KE, Barreto TSP, Silva AG (2018) Agricultura de Precisão: Programas Tecnológicos no Brasil. Revista Geama, 4(2):23-30.

MAPA. (2016). Ministério da Agricultura. Disponível em: $<$ http://www.agricultura.gov.br/vegetal/culturas/citrus $\geq$ (Acesso em 22 Jun 2016).

Massruhá SMFS, Leite MAA (2016) Agricultura digital. Revista Eletrônica Competências Digitais para Agricultura Familiar, 2(1):72-88.

Matsunaga M, Bemelmans PF, Toledo PEN, Dulley RD, Okawa H, Pedroso IA (1976) Metodologia de custo de produção utilizada pelo IEA. Agricultura em São Paulo, 23(1):123-139.

Müller MD, Nogueira GS, Castro CRTD, Paciullo DSC, Alves FDF, Castro RVO, Fernandes EN (2011) Economic analysis of an agrosilvipastoral system for a mountainous area in Zona Mata Mineira, Brazil. Pesquisa Agropecuária Brasileira, 46(10):1148-1153. doi: 10.1590/S0100-204X2011001000005

Mun J (2002) Real options analysis: Tools and techniques for valuing strategic investments and decisions. John Wiley \& Sons. 386p.

Nam WH, Kim T, Hong EM, Choi JY, Kim JT (2017) A Wireless Sensor Network (WSN) application for irrigation facilities management based on Information and Communication Technologies (ICTs). Computers and Electronics in Agriculture, 143:185-192. doi: 10.1016/j.compag.2017.10.007

Novaes AL, Santos LC (2017) Sistema de monitoramento veicular-setores sucroalcooleiros: a tecnologia da informação a serviço da gestão empresarial. Colloquium Agrariae, 13(Especial):262-267. doi: 10.5747/ca.2017.v13.nesp.000203

Neves MF, Kalaki RB (2015) Citricultura: Perspectivas para a produção brasileira. Agroanalysis, 35(6):26-27 .

Oliveira LG, Paiva EJ, Paiva AP (2019) Aplicação do método de Monte Carlo para a previsão de falhas: uma ferramenta de apoio à gestão da manutenção. Revista Produção Online, 19(1):72-101. doi: 10.14488/16761901.v19i1.3091

Oliveira MRG, Medeiros Neto LB (2012) Simulação de Monte Carlo e Valuation: uma abordagem estocástica. Revista de Gestão, 19(3):493-511. doi: 10.5700/rege474
Oliveira RJ, Pamplona EO (2012) A volatilidade de projetos industriais para uso em análise de risco de investimentos. Gestão \& Produção, 19(2):337-345. doi: 10.1590/S0104-530X2012000200008

Paes AR, Esperancini MST (2006) Análise de rentabilidade da citricultura da região Sul Paulista, sob condições de risco, em três densidades de plantio. Revista Energia na Agricultura 21(1):18-33.

Paulillo LF, Neves MC (2015) Análise das estruturas de governança de compra de laranja dos maiores packing houses no estado de São Paulo: um estudo multicasos sobre arranjos híbridos. Organizações Rurais \& Agroindustriais, 17(4):461-478.

Regattieri AL, Regattieri CR, Vidal DO (2018) Monitoramento de frotas no setor citrícola. Revista Interface Tecnológica, 15(1):349-359.

doi:

10.31510/infa.v15i1.341

Ribeiro TR, Franco MR (2017) Retorno econômico da citricultura versus cultivo de grãos na região de Paranapanema-SP. Revista IPecege, 3(4):35-47. doi: 10.22167/r.ipecege.2017.4.35

Sabbag OJ, Costa SMAL (2015) Análise de custos da produção de leite: aplicação do método de Monte Carlo. Extensão Rural, 22(1):125-145. doi: 10.5902/2318179614153

Scaloppi EMT, Aguiar RL, Goes AD, Spósito MB (2012) Efeito do manejo cultural e químico na incidência e severidade da mancha-preta dos citros. Revista Brasileira de Fruticultura, 34(1):102-108. doi: 10.1590/S0100-29452012000100015

Santos DFL, Mendes CC, Farinelli JBM, Farinelli R. (2016). Viabilidade econômica e financeira na produção de cana-de-açúcar em pequenas propriedades rurais. Custos e @gronegócio online. 12(4):222-254.

Silva ELD, Ferreira MAM, Monteiro DAA (2011) Viabilidade financeira da produção de feijão em sistema automatizado de irrigação por miniaspersão. Organizações Rurais \& Agroindustriais 13(2):290-302.

Spada L (2011) Danos causados pela podridão floral dos citros em diferentes variedades de laranja doce. Fundo de Defesa da Citricultura (Dissertação de Mestrado em Fitossanidade).

Simões D, Cabral AC, Oliveira PAD (2015). Citriculture economic and financial evaluation under conditions of uncertainty. Revista Brasileira de Fruticultura, 37(4):859-869. doi: 10.1590/0100-2945-257/14

Tank Junior A (2013) Eficiência de fungicidas no controle da podridão floral dos citros sob chuvas simuladas em pomar de laranja doce. Fundo de Defesa da Citricultura (Dissertação de Mestrado em Fitossanidade). 
Toledo AD, Silva RPD, Furlani CEA (2013) Quality of cut and basecutter blade configuration for the mechanized harvest of green sugarcane. Scientia Agricola, 70(6):384-389. 90162013000600002

doi:

10.1590/S0103-

Voltarelli MA, Silva RP, Zerbato C, Silva VA, Paixão CS (2015a). Monitoramento das perdas no processo de colheita mecanizada de tomate industrial. Revista Engenharia na Agricultura, 23(4):315-325. doi: 10.13083/reveng.v23i4.533
Voltarelli MA, Silva RP, Zerbato C, Paixão CS (2015b). Quality indicators of soybean conventional and crossseeding. Científica, 43(4):309-315. doi: 10.15361/19845529.2015v43n4p309-315

Xia C, Wang L, Chung BK, Lee JM (2015) In situ 3D segmentation of individual plant leaves using a RGB-D camera for agricultural automation. Sensors, 15(8):20463-20479. doi: 10.3390/s150820463 